\title{
ФЕНОМЕН КОРЕЙСЬКОЇ ЕМОЦІї ХАН: ЕТИМОЛОГІЯ, ІСТОРІЯ, ДУХОВНІСТЬ
}

\author{
Ірина ЗБИР \\ Кандидат філологічних наук, доцент Корейського університету іноземних мов Хангук \\ (РЕСПУБЛІКА КОРЕЯ) \\ email: ivtorak@gmail.com \\ UDC: [130.2:159.942](519) \\ https://orcid.org/0000-0001-5852-2002
}

DOI 10.25128/2304-1222.20.50.12

\begin{abstract}
The article deals with the phenomenon of Korean emotion han in the light of historical, religious, social and cultural life of the Korean people. It is a basic and unique feeling that organizes and in some way structures the world of Korean emotions in general and each individual Korean in particular. The aim of this study is to analyze the content of the Korean concept han and unique meaning of the term, give examples of ways to overcome it, and pay particular attention to certain aspects of the historical, religious, social, cultural and political life of Koreans, which is closely related with emotion han. Despite the difficulties in interpreting of this concept, many researchers believe that this is a unique Korean collective sense of pain that is common to all Koreans.
\end{abstract}

Key words: emotion han, feeling, Korea, Korean people, experience.

У статті розглянуто феномен корейської емоції хан крізь призму історичного, релігійного, соціальнокультурного життя корейського народу. Це основне і своєрідне почуття, що організовує і певним чином структурує світ корейської емоційності в цілому та кожного окремого корейця зокрема. Проаналізовано зміст корейського поняття хан та унікальні значення цього терміна, наведено приклади шляхів його подолання, а також особливу увагу звернено на деякі аспекти історичного, релігійного, соціально-культурного та політичного життя корейців, що тісно пов'язані з емоцією хан. Незважаючи на труднощі у тлумаченні цього поняття, багато дослідників вважають, що це унікальне корейське колективне почуття болю, яке притаманне всім корейцям.

Ключові слова: емочія хан, почуття, Корея, корейський народ, досвід.

Artykuł dotyczy fenomenu koreańskiej emocji han w świetle historycznego, religijnego, społecznego i kulturalnego życia narodu koreańskiego. Jest to podstawowe i wyjątkowe uczucie, które organizuje i w pewien sposób kształtuje świat koreańskich emocji w ogóle, a w szczególności każdego Koreańczyka. Celem tego tekstu jest analiza treści koreańskiego han i unikalnego znaczenia tego terminu, podanie sposobów jego przezwyciężenia oraz zwrócenie szczególnej uwagi na niektóre aspekty życia historycznego, religijnego, społecznego, kulturalnego i politycznego Koreańczyków, którzy są ściśle związani z emocją han. Pomimo trudności w interpretacji tego pojęcia, wielu badaczy uważa, że jest to unikalne zbiorowe poczucie bólu wspólne dla wszystkich Koreańczyków.

Słowa kluczowe: emocja han, uczucie, Korea, Koreańczycy, doświadczenie.

Постановка проблеми. Вивчення корейської традиційної культури та ментальності неможливе без поняття хан, що міцно вкоренилося в мові, релігії та філософії корейців. Це основне і своєрідне поняття, що організовує і певним чином структурує світ корейської емоційності в цілому і кожного окремого корейця зокрема. Тому, досліджуючи специфіку корейського феномена хан, що є важливим елементом його ідентичності, варто пригадати 
поняття «культурних сценаріїв» (,skryptów kulturowych”) Анни Вєжбіцкої [Wierzbicka 1999: 163-188].

Дослідниця зазначила, що коли ми говоримо про емоції, кожна культура використовує власні зразки та погляди, а у випадку цього настільки неоднозначного явища хан, що поширене як в Кореї, Китаї, так і в Японії, варто пам'ятати, що в кожній з цих країн слово, що виражає складні емоції, з якими вони пов'язані, означає щось подібне, але в той же час відноситься до дещо іншої категорії.

Аналіз основних досліджень і публікацій. Поняття хан викликало інтерес як у корейських, так й іноземних дослідників. Якщо корейські вчені у різні періоди історії крізь призму цієї емоції намагалися пояснити власні здобутки та досягнення, переживання та втрати, гордість і національну самобутність, то іноземці, як правило, наголошували на унікальності цього поняття в корейській культурі та шукали екзотичний матеріал для своїх компаративістичних студій. Зокрема, це праці таких дослідників як Ендрю Сунг Парк [Park 1993], Дже Х. Лi [Lee 1994], Чанг Х. Сон [Son 2000], Лі Йонг Xi [Lee 2004], О Кьонг Гин [Oh 2013] та інші. В Україні лише наприкінці 90-х - на початку 2000-х років почали досліджувати це явище, вивчаючи історію, літературу, культуру Кореї загалом (І. Семенюк, А. Налімова, Ю. Ковальчук). Тому актуальність нашого дослідження полягає у створенні комплексної розвідки про феномен хан в корейській культурі, а запропонована стаття - це лише перший крок на цьому шляху.

Мета статті - 3'ясувати зміст корейського поняття хан та унікальні значення цього терміна, навести приклади шляхів його подолання, а також розглянути деякі аспекти історичного, релігійного, соціально-культурного та політичного життя корейців, що тісно пов'язані з емоцією хан.

Виклад основного матеріалу. У корейській мові є три слова, які мають однакове звучання, але різні значення (і походження): хан (韓) - назва корейської нації ${ }^{8}, x a н$ (한) прикметникова форма корейського слова, що означає єдність (спільність) ${ }^{9}$, і хан (踚) позначення глибоких людських страждань як один з аспектів корейської культури. У цьому дослідженні корейське слово хан буде розглядатися як емоція страждання, що є унікальним корейським явищем.

Корейсько-американський богослов Ендрю Сунг Парк зауважив: «Хан - це азійський, зокрема корейський, термін, що використовується для опису глибини людських страждань.

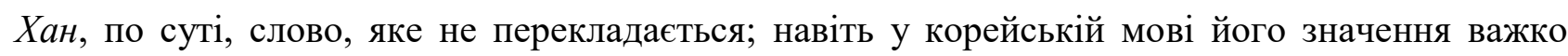
окреслити. Хан - це страшний досвід болю» [Park 1993: 15]. Дже Х. Лі, яка вперше ввела

\footnotetext{
${ }^{8}$ Інше слово ХАН (漢), яке вимовляється так само, але відрізняється китайським ієрогліфом і позначає одну 3 китайських династій або етносів (клану).

${ }^{9}$ Це виключно корейське слово і немає відповідника у китайській мова.
} 
слово «хан» у англомовний світ, опублікувавши свою дисертацію, зазначила, що «хан - це не одне почуття, а комплекс почуттів, що включає обурення, жаль, відмову, агресію, тривогу, самотність, тугу, смуток і порожнечу. Воно навіть охоплює такі суперечливі почуття, як ненависть і любов» [Lee 1994: 2].

Отже, як зауважили вище провідні корейські вчені 3 дослідження хан, цей термін називає складні почуття та досвід, які важко окреслити одним словом чи поняттям, навіть корейцям. Незважаючи на труднощі у визначенні поняття хан, в Кореї протягом останніх 60ти років було зроблено кілька спроб тлумачення цього поняття іншими корейськими вченими і митцями.

У 1960-х роках Чунг Чун Кім, корейський дослідник Біблії, застосував концепцію хан до своєї старозавітної герменевтики. Під впливом ліберальної теології Південної Америки та глобальних постмодерністських богословських тенденцій, Кім тлумачив хан як страждання гноблених Мінджунг ${ }^{10}$, як це описано у Старому Завіті. Протягом 1970-80-х рр. з'явилися богослови Мінджунг і почали займатися поняттям хан як основним теологічним предметом [Park 1993, Lee 1994, Son 2000]. Ці дослідники використовували хан насамперед як термін для означення переважно соціально-економічного та політичного страждання простого народу.

Проте, починаючи з 1990-х років після громадянської перемоги над військовою диктатурою в соціально-політичному житті Кореї, вчені Мінджунг почали застосовувати концепцію хан у більш широкому і цілісному розумінні - до історії корейського народу, мистецтва, культури, життєвого досвіду та духовності. Лі досліджувала хан з психологічної точки зору: «Під пригніченими почуттями існують психологічні рани, які є результатом досвіду розчарування і психологічного болю. Ці рани несуть відповідальність за придушення певних почуттів і, отже, за створення емоції хан» [Lee 1994: 3]. Натомість Чанг Х. Сон розглядав хан як форму духовності: «Хаан ${ }^{11}$ глибоко вкорінений як у внутрішньому, так і у зовнішньому вимірах корейського життя, оскільки корейці постійно взаємодіють із зовнішнім світом, відчуваючи його внутрішньо. Хаан також глибоко пов'язаний з духовними вимірами світогляду корейців і того, що люди є духовними істотами [Son 2000: 16].

Етимологічно, в більш широкому значенні, хан є насамперед азійським терміном, який використовується для опису людських страждань. Парк наводить переклади цього терміна в інших мовах: «Хан - це хен (кит. „ненависть”), кон (япон. „зневажати”), хоросул (мон. „смуток”), корсоцука (манджур. „ненависть, горе”), і хан (в’єт. „розчарування”)» [Рark 1993: 180]. Лі навіть намагалася вивести концепцію хан з санскриту Стародавньої Індії: «,Uрапаһа”, яка спочатку означала „фіксацію до речей”, а згодом перетворилася на більш

\footnotetext{
10 Мінджунг (Minjung) - термін на означення гноблених простих людей, який протягом багатьох років використовували дослідники, що вивчали теологію.

11 Дослідник користується дещо іншим терміном на позначення емоції хан, однак інтерпретує його так само, як і інші вчені. 
складне поняття, що охоплює ненависть, залякування і зло» [Lee 1994: 2]. Сон проаналізував китайський ієрогліф слова «хан», походження якого можна простежити 3 двох китайських

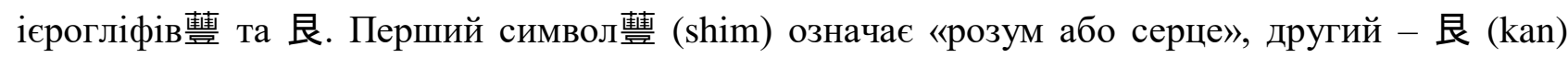
«залишатися тихим або спокійним». Сон стверджує, що «китайський ієрогліф踚 - це зображення дерева, коріння якого знаходиться глибоко-глибоко під землею» [Son 2000: 4]. На його думку, хан - це глибока рана серця, яка часто $\epsilon$ невидимою.

Наведені вище визначення зосереджені на тлумаченні індивідуального досвіду хан, однак походження цього поняття починається насправді з колективного людського досвіду корейського народу. Лі стверджує, що всі корейці мають свої оригінальні рани. Феномен почуття хан як колективної емоції корейського народу полягає в його ставленні до корейської культури та історії [Lee 1994: 3]. Це дає правильне тлумачення своєрідності корейського хан. Отже, Лі визначає його так: «Унікальність корейського хан полягає в багатстві його змісту та зв'язку з повсякденним життям людей та їх культурою» [Lee 1994: 2]. Якщо говорити про своєрідність хан, що належить виключно корейцям, то слід розглядати його колективні аспекти.

Цей колективізм можна пояснити психологічним поняттям Карла Юнга «колективного несвідомого» [Park 1993, Lee 1994)]. Однак Парк не погоджується 3 колективним несвідомим Юнга як універсальним людським досвідом. Його тлумачення зосереджено на особливому досвіді суспільно-політичних жертв корейського народу та емпіричних аспектах колективного несвідомого як характерний корейський досвід. Однак можна припустити, що хан як колективне несвідоме зберігає фундаментальну універсальність для всіх людей в понятті «архетип» Юнга. Тоді, тлумачення Лі колективного $x a \mu$, як культурних та міжкультурних явищ, що 3'являються в корейському шаманізмі, $\epsilon$ ближчими до «колективного несвідомого» Юнга. За допомогою шамана (примітивного посередника-цілителя) корейський народ здатний висловити несвідоме прагнення зцілювати свою патологію хан і відновити цілісність людини як універсальної особи. Однак шаманізм не єдиний метод у подоланні хан як колективного несвідомого корейського народу.

Існують інші способи подолання хан. Зокрема, поет Мінджунг, Чі Ха Кім, окреслив концепцію дан, що означає «відсікання» або «відрізання» [Lee 1994, Son 2000]. Лі зазначила: «На думку Кіма, хан відповідає за створення порочного кола насильства і репресій, і це коло повинно бути порушено практикою дан [Lee 1994: 152]. Натомість Парк, який безпосередньо не згадує дан, зазначає, що «роз'єднання» i «трансцендентність» від порочного кола реальності хан є способом його подолання. Однак, корейці не впевнені, що дан - це єдиний метод у подоланні цього почуття. Вони також використовують такі поняття, як джонг 
(«чиста прихильність») і шин («божественність») як потенційні шляхи вирішення або подолання хан.

Отже, поняття хан важко окреслити не тільки українською, але й корейською мовами. Тут слід розглянути деякі аспекти історичного, релігійного, культурно-соціального та політичного життя корейців.

Багато дослідників вважають, що поняття хан 3 його колективним досвідом притаманне всьому корейському народу. Проаналізувавши історію Кореї від найдавніших часів і до сьогодні, можна простежити, що зневіра і страх були присутні у житті корейців протягом багатьох років, та навіть століть. Зокрема, історія Кореї XX ст. сповнена драматичних сторінок: це японська окупація 1910 р., Друга світова війна та Корейська війна 1950-1953 pр. тощо. Тому вчені та митці Кореї використовують поняття хан, щоб надати трагічного забарвлення не лише періоду японського колоніалізму (деякі з них вважають цей час періодом запровадження та активного використання цього терміна), але й подіям, що відбувалися і в другій половині XX ст.

Географічне положення Корейського півострова між сильними сусідніми країнами (Китай, Японія, Росія) спричинило, що протягом історії він кілька разів був окупований. Корейський народ з болем і скорботою згадує дві великі окупації: японське вторгнення в Корею в 1592-1598 pp. і Маньчжурську війну 1636 р.: «Вторгнення Японії не мало на меті нічого, крім того, щоб зруйнувати Корею, залишивши після себе голод, хвороби і пустелю... Під час руйнування, ледве встояли будівлі, за винятком кам'яних. Економіка і соціальне життя були повним хаосом протягом багатьох років... Бажаючи зберегти свої сили для великого нападу на Китай, маньчжури були задоволені лише тим, щоб забезпечити, аби Чосон (корейська династія) не могла діяти проти них... Корейський король відмовився прийняти васальний статус у 1636 році, маньчжурський правитель перейшов на трон, коли імператор Китаю Цін знову вторгся в Корею. Король Інджо (корейський) втік, а згодом зрікся престолу» [The Korean Overseas Information Service 1986: 73-74].

На початку XX ст. агресія Японії щодо Кореї знову почала зростати. Японія насильно анексувала Корею в 1910 р. і це тривало до поразки її у Другій світовій війні. Протягом цього колоніального періоду корейський народ сильно постраждав від Японії. Японці вчинили жахливі, нелюдські злочини проти корейців: багато молодих корейських жінок насильно вивозили до зони бойових дій і використовували як сексуальних рабинь, щоб задовольнити японських солдатів; корейські юнаки працювали робітниками на заводах і фабриках, а також служили в японській армії, часто відправляли їх на передову, де вони слугували людським щитом. Крім того, японці грабували корейську землю i навіть проводили медичні експерименти на живих людях. 
Після закінчення Другої світової війни в 1945 р. Корея була розділена на дві частини: Північ Корейського півострова окупував Радянський Союз, а Південь - США. Спроби відтворити єдину корейську державу провалилися, і в 1948 р. були проголошені Республіка Корея i Корейська Народно-Демократична Республіка (КНДР) 15 серпня і 9 вересня відповідно. Корейський народ знову наблизився до національної трагедії в 1950 р., коли почалася Корейська війна 1950-1953 pр. Корейський півострів став сплюндрованим місцем для «обмеженої війни» (,limited war”) [Cummings 2010] у час холодної війни між великими комуністичними країнами Радянського Союзу і Китаю та капіталістичними державами США i iï союзниками.

Сьогодні Корея - це єдина нація у світі, що залишається ідеологічно та фізично розділеною. Крім того, Корейська війна не закінчилася, а лише припинила активну фазу бойових дій на півсторіччя. Північ і Південь залишаються формально в стані війни. За режиму трьох поколінь правлячої династії Кім ${ }^{12}$ населення Північної Кореї постраждало від комуністичної диктатури, втративши свої права і свободи. Протягом останніх декількох десятиліть воно пройшло випробування голодом та економічними труднощами, не задовольняючи навіть основні людські потреби. Мільйони дітей померли від голоду. Досвід $x a н$ північних корейців виявив себе як сильно мстиве ставлення до США та лідерів держави Республіка Корея, вважаючи їх імперіалістичними ворогами, які експлуатують i переслідують корейців з Півночі.

3 іншого боку, Південна Корея також постраждала від режиму військової диктатури, що тривав до кінця 1980-х років. Генерал Парк Чун Хі захопив владу шляхом військового перевороту в 1961 р. і був президентом Республіки Корея до вбивства в 1979 р. Проте багато інтелігенції та студентів, які організовували протести та демонстрації, були переслідувані та вбиті жорстоким військовим режимом. Мільйони робітників фабрик і заводів працювали у надважких умовах.

У той час багато корейців змушені були емігрувати у пошуках кращого життя. Зокрема, будівельники виїжджали в країни Близького Сходу, шахтарі та медсестри - у Західну Німеччину (ФРН), солдати та офіцери - на війну у В’єтнамі 1959-1975 pp. i проливали свою кров як найманці, щоб отримати фінансову допомогу від Сполучених Штатів для побудови інфраструктури уряду Парк Чун Хі в Південній Кореї. Наступник Парка, генерал Ду Хван Чун, захопив владу після жорстокого придушення повстання та вбивства протестувальників у Кванджу в 1980 р. Однак це повстання стало поворотним моментом в історії сучасної Кореї: «Воно (повстання - 3.I.) є незаперечним свідченням жорстокості військового режиму, але водночас стало рушійною силою демократичного руху,

\footnotetext{
12 Кім Ір Сен, Кім Чен Ір, Кім Чен Ин.
} 
що наступав. Цей рух завершився протестом у червні 1987 p; і з того часу відбувається поступовий прогрес у політичній демократії» [Han 2005: 1000].

Після здобуття демократії права корейського народу стали покращуватися, а літні Олімпійські ігри в Сеулі 1988 р. вселили корейцям відчуття соціально-економічного зростання та стабільності. Проте у 1997 р. Республіка Корея зазнала серйозної економічної кризи і вимагала порятунку в Міжнародного Валютного Фонду. Однак згуртованість корейців навколо ідеї самопожертви заради порятунку економіки країни, перевершила очікування. За даними організаторів, «було зібрано десять тонн золота за перші два дні кампанії... Але, мабуть, найбільш незвичним аспектом кампанії були не суми, а готовність корейського народу приносити особисті жертви, щоб допомогти зберегти свою економіку» [Koreans give up their gold to help their country 1998]. Республіка Корея подолала кризу МВФ i стала однією з найбагатших країн світу. Досвід хан населення Південної Кореї працював у позитивному напрямку, виявляючи силу подолання труднощів.

Незважаючи на успіхи та перемоги протягом тривалого періоду історії, досвід хан має й негативні наслідки для корейського народу. Сьогодні корейці все ще страждають від високого рівня самогубств, зниження народжуваності, жорстокої конкуренції, але не втрачають надію на майбутнє. Також Корейський півострів є одним з найбільш нестабільних регіонів світу, де між Північчю і Півднем формально продовжується війна.

Не лише історія Кореї, а й духовність як релігійна основа корейського національного характеру, глибоко пов'язані з досвідом хан. У сучасному корейському суспільстві співіснують поряд різні релігії. Це буддизм, конфуціанство, шаманізм, даосизм, а 3 кінця XVII ст. християнство. Кожна релігія та філософська ідеологія мали прямий чи опосередкований вплив на формування корейського хан, оскільки були причиною його виникнення або сприяли його піднесенню.

Дон Бейкер зазначив, що «спектр релігійних вірувань і практик в Кореї ширший, ніж в будь-якому іншому місці на землі» [Baker 2007: 1]. Найдавнішою корейською релігією $є$ шаманізм [Yu 1988], який і досі практикується в Південній Кореї. Протягом минулого століття християнство, як остання релігійна течія, набула значного розквіту в Кореї і мала потужний соціальний вплив на розвиток країни. На додаток до шаманізму і християнства, багато корейців вважають, що суть традиційного корейського духу - це Ю-Бул-Сон (育䓯菌, конфуціанство, буддизм і даосизм). Незважаючи на те, що ці три релігії походять 3 китайської культури [Baker 2007], корейці приділяють велику увагу традиційному Ю-БулСон духу, культурі та релігійній ментальності як своїй власній. Корейський народ вважає, що ці три релігії переплелися в єдине ціле. Отже, шаманізм, буддизм, конфуціанство, даосизм і християнство, вплинули на корейський спосіб життя, культуру і, отже, тісно пов’язані з їхнім досвідом хан. 
Конфуціанство як філософсько-релігійна система було запозичене в Китаї у I ст. н. е., ставши домінуючою державною доктриною протягом багатьох століть. У кінці XIV ст. воно переросло в неоконфуціанство, яке домінувало в країні понад 500 років (до 1910 р., коли Японія окупувала Корею). Неоконфуціанство стало жорстокою версією попередньої ідеології, та з часом мало великий вплив на всі сфери життя корейців [Oh 2013: 127-131, De Mente 2004]. Це створило умови для появи хан. Суворе ставлення до моралі, поводження 3 жінками та слабшими людьми означало, що ті, хто відчуває смуток, розчарування та біль, почали створювати пісні про нього, вистави народного театру - у формі танцю в масках, лялькового театру, театру тіней чи музичної монодрами Пансорі. Деякі з цих театральних форм збереглися до наших днів, навіть внесені до Списку всесвітньої спадщини. Наприклад, це танець у масках Бонсан (1967) та музична монодрама Пансорі (2003) [Oh 2013: 112].

Буддизм проник у Корею в 372 р. Нову релігію та філософію прийняли переважно багаті люди - члени королівської родини та знаті. Його основний принцип грунтувався на індивідуальному просвітленні особистості, головним завданням якого було досягнення нірвани. Однак це було доволі непросто, адже його отримували постійним самовдосконаленням та звільненням від поганих емоцій. Такі правила для пересічної людини стали надто вимогливими. Невдовзі ченці були вигнані з храмів офіційною владою під приводом проповіді поверхневих, непросвічених гасел, а послідовники конфуціанства називали буддизм помилковою та аморальною релігією. Згодом неоконфуціанство як офіційна державна ідеологія визнало, що всі релігії це єресь, і заборонили їх сповідувати. Тому така доля спіткала не лише буддизм, але й даосизм і шаманізм [Oh 2013: 85-91].

Шаманізм став провідною релігією для тих корейців, які вважали принципи буддизму надто вимогливими. Його головно сповідували люди нижчих соціальних верств, які розуміли, що хан може застосовуватися і до мертвих. У своїх ритуалах він мав справу зі злими духами, тобто душами тих, хто відійшов. Оскільки вважалося, що у кожної померлої людини був якийсь хан, а смерть - результат злого духа, який все ще обурюється. Щоб позбутися його, потрібні були спеціальні ритуали. Саме тому корейці так охоче брали участь у них, і це був найпростіший спосіб звільнитися від поганих емоцій та подолати хан [Кіm 2015, Ryu 2012, Kim 2003].

Популярність шаманізму серед корейців зростала, тому що простий народ знайшов у ньому спосіб заспокоїти духів людей, у яких було багато хан в житті, а ритуали допомогли звільнитися від нього. Отже, у Кореї виникли специфічні відносини - у той час, коли офіційне конфуціанство своєю жорстокістю спричиняло або посилювало хан, шаманізм допомагав подолати його. На думку Лі, «корейський шаманізм - це найбільш ретельний синтез даосизму і буддизму. Ці дві вищі форми релігії стали настільки тісно поєднані 3 шаманізмом, що ... (неможливо) їх розділити» [Lee 1981: 1]. У Південній Кореї шаманізм не 
тільки сильно вплинув на буддизм і даосизм, але й на християнство. Багато корейських християн мають шаманський спосіб висловлення своєї віри [Han 1994].

Християнство, яке було запроваджено в Кореї за посередництвом Китаю, зараз є дуже популярною релігією - близько 30\% громадян країни визнають, що вони є протестантами чи католиками. Тут варто відзначити, що християнська релігія допомогла жінкам поступово зменшити почуття хан та полегшити розчарування. Завдяки тому, що християнство звернуло увагу на людську суб’єктивність і відкинуло принцип ізоляції жінок, воно створило можливості для їх соціальної активності. Як наслідок, це дало реальну можливість позбутися безперервного жалю та поступово змінити життя, саме тому воно стало популярне серед корейців [Oh 2013: 55].

Невипадково поняття хан традиційно було пов'язане з образом жінки, їі нелегкою долею. Жінка в корейської традиції завжди стояла нижче чоловіки в соціальній ієрархії, вона у всьому йому підпорядковувалася. Її не називали навіть власним іменем, а тільки на ім'я батька, чоловіка, а потім і сина. Покірність, покірність і ще раз покірність - такою була головна чеснота жінки. Жінка не мала ніяких прав. Її роль полягала в заміжжі і народженні дітей. Законом було встановлено, що жінка після заміжжя повинна жити в будинку чоловіка, вдови повинні були зберігати вірність родині свого померлого чоловіка до самої смерті, $\mathrm{i}$ якщо вони вирішувалися повернутися до батьківського дому або знову вийти заміж, то їх дітей залишали в родині померлого чоловіка. Як би безжально чоловік не поводився 3 дружиною, їй належало мовчки підкорятися його волі. Вона не могла повернутися до рідного дому, тому що це вважалося ганьбою для їі родини. Про розлучення жінці не можна було навіть і думати [Ли 2010: 153].

Усі сторони суспільного та родинного життя корейського народів знайшли відображення в народній творчості, світогляді тощо. Зокрема, емоція хан доволі детально характеризує низьке соціальне становище жінки в традиційному корейському суспільстві та уособлює іiі біль, ненависть, образу і жаль. Однак, на думку дослідниці Лі Йонг Хi, хан для корейської жінки це не просто підкорення тій життєвій ситуації, яка склалася, а й вихід 3 неї, що може принести радість і задоволення. Цей термін виходить за межі горя і приносить комфорт у життя. Дуже часто виконання пісень допомагало жінкам подолати їхню біль i вони (пісні - I. 3.) залишаються цінним джерелом жіночого болю, жалю, смутку та образи. Лі стверджує, що «пісня як ліки, яка дає тимчасове полегшення від болю, що заповнило іiі серце» [Lee 2004: 28].

У корейських народних піснях про жіночу долю найпоширенішими мотивами $є$ насильне заміжжя, життя з нелюбом, стосунки зі свекрухою та іншими родичами чоловіка, життя далеко від рідної домівки, неможливість повернення, життя вдови, покритки та інші 
[див.: Збир 2019: 377-384]. Саме корейський фольклор є багатющим джерелом дослідження емоції хан у житті жінки.

Тут слід згадати найвідомішу корейську пісню «Аріранг», що у 2012 р. була внесена до Списку всесвітньої спадщини ЮНЕСКО, яка відома не лише в Південній, але і в Північній Кореї. Хоча у двох країнах побутують дещо відмінні варіанти пісні, але протягом 300 років вона була настільки популярною, що стала символічним гімном представників обох держав під час Олімпійських ігор у Сіднеї 2000 р. та в Афінах 2004 р. Найвідоміший варіант пісні - «Кьонгі Арірінг» або «Сеул Арірінг». У строфі, що найчастіше виконується, розповідається про розлуку дівчини з коханим хлопцем, яка, відчуваючи сум, жаль, образу, посилає дивне прокляття на свого коханого: щоб заболіли його ноги під час подорожі через пагорб Аріранг. Як зазначають дослідники, співане прокляття - це також парадоксальна надія жінки відвернути нещастя. Сьогодні пісня є дуже важливою для корейців - вони трактують їі як символ важкої долі, а пагорб асоціюється з подоланням життєвих негараздів та перемог [Oh 2013: 107-109].

Висновки. Отже, хан - це унікальне корейське колективне почуття болю, яке притаманне всім корейцям. Це внутрішня емоція, що охоплює горе історичної пам'яті пам'ять про минулу колективну травму - i супроводжується сильним тиском, який не дозволяє відкрити істину страждання. Тому хан відрізняється від того, що в західній культурі виражає «пам'ять страждань». У корейській культурі поняття хан виникло внаслідок особливої сукупності історичних явищ. На формування цього феномена мали визначальний вплив три фактори: 1) геополітичний, пов'язаний з постійним вторгненням сусідніх держав на територію країни, 2) етичний, пов’язаний з конфуціанської ідеологією, 3) родоплемінний, пов'язаний із сімейним авторитаризмом.

Феномен хан та його парадокс полягає у суміші суперечливих почуттів i, нарешті, позитивний ефект від подолання негативних емоцій. Це корейське почуття нагадує прозору відфільтровану воду, з якої були вилучені негативні емоції - образа та ненависть. Це означає, що людина, яка переживає темну сторону хан, може її подолати і, долаючи труднощі, будує майбутнє. Сила, необхідна для їх побудови, - це світла сторона болю. Отже, хан стає інструментом, який створює цінності, а також визначає ідентичність спільноти, що схоже на катарсис, який нікому не шкодить, але приносить конкретні плоди.

\section{ЛIТЕРАТУРА}

Baker, D. (2007), Introduction, In: Religions of Korea in Practice, R. E. Buswell Jr. (Ed.), Princeton, New Jersey. 1-31.

Cumings, B. (2010), The Korean War: A History. New York.

De Mente, B. L. (2004), NTC's Dictionary of Korea's Business and Cultural Code Words. Singapore.

Han, Gil Soo (1994), Social Sources of Church Growth: Korean Churches in the Homeland and Overseas. Lanham, Maryland.

Han, In Sup Kwangju and Beyond: Coping with Past State Atrocities in South Korea, „Human Rights Quarterly", 2005, 27, s. 998-1045. 
Kim, Chongho (2003), Korean shamanism: The cultural paradox. Aldershot, Hampshire, UK.

Kim, Inwhoe (2015), Life Education Shamanism: Korean Shamanism from an Educator's Perspective, In: Kim, Inwhoe Photographs Collections. Seoul:.

Korean Overseas Information Service. In: Focus on Korea: Korean History, Seoul: Seoul International Publishing House, 1986.

Lee, Jung Young (1981), Korean Shamanistic Rituals. The Hague, Paris, New York.

Lee, Jae Hoon (1994), The Exploration of the Inner Wounds-HAN. Atlanta, Georgia.

Lee, Younghee (2004), Ideology, Culture, And Han: Traditional and Early Modern Korean's Women's Literature. Seoul-Edison.

Oh, Kyong Geun (2013), Uczucie han jako wartość estetyczno-moralna w kulturze i literaturze narodu koreańskiego. Poznań.

Park, Andrew Sung (1993), The Wounded Heart of God: The Asian Concept of Han and the Christian Doctrine of Sin. Nashville.

Ryu, Tongshik (2012), The history and structure of Korean shamanism. Seoul.

Son, Chang Hee (2000), Haan (咕, 踚) of Minjung Theology and Han (孉, 踦) of Han Philosophy: In the Paradigm of Process Philosophy and Metaphysics of Relatedness. Lanham, Maryland.

Wierzbicka, A. (1999), Emocje. Język $i$,skrypty kulturowe”. W: Język - umyst - kultura, (red.) J. Bartmiński. Warszawa. 163-188.

World (1998), World: Analysis - Koreans give up their gold to help their country BBC News. January 14. URL: http://news.bbc.co.uk/2/hi/world/analysis/47496.stm [20.05.2020]

Yu, Chai Shin (1988), Korean Taoism and Shamanism, In: Shamanism: The Spirit World of Korea, R.W.I. Guisso \& C. S. Yu (Eds.), Berkeley, California. 98-118.

3бир, I. (2019), Порівняльний аналіз образу жінки в українській і корейській культурах (на основі праці Івана Франка «Жіноча неволя в руських піснях народних»). В: Іван Франко «Я єсть пролог...»: матеріали Міжнародного наукового конгресу до 160-річчя від дня народження Івана Франка: у 2 т. Львів. Т. 2. 373-386 [Zbir, I. (2019), Porivnyal'niy analiz obrazu zhinki v ukrayins'kiy i koreys'kiy kul'turakh (na osnovi pratsi Ivana Franka „Zhinocha nevolya v rus'kikh pisnyakh narodnikh"). V: Ivan Franko „Ya yest' proloh...»: materiali Mizhnarodnoho naukovoho konhresu do 160-richchya vid dnya narodzhennya Ivana Franka: $u 2$ t. Lviv. T. 2. 373-386].

Ковальчук, Ю. А. (2017), Образи корейських жінок у місіонерській прозі початку ХХ століття. В: Тексти доповідей міжнародної наукової конферениї «Кореєзнавство в Украйні: сучасність і перспективи». Київ. 148-159 [Koval'chuk, Yu. A. (2017), Obrazi koreys'kikh zhinok u misioners'kiy prozi pochatku XX stolittya. V: Teksti dopovidey mizhnarodnoyi naukovoyi konferentsiyi "Koreyeznavstvo v Ukrayini: suchasnist' $i$ perspektivi». Kiyiv. 148159].

Ли, Кван Сун (2010), Социально-философский анализ семьи (на примере корейской семьи). Философия и общество. Москва. № 3. 149-161 [Lee, Kyong Sung (2010), Sotsial’no-filosofskiy analiz semyi (na primere koreyskoy semyi). Filosofiya i obsshestvo. Moskva. No 3. 149-161].

Налімова, А. О. (2017), Концепт «хан» (한) у сучасній корейській малій прозі. В: Тексти доповідей міжнародної наукової конференції «Кореєзнавство в Украӥні: сучасність $i$ nерспективи». Київ. 228-234 [Nalimova, А. O. (2017), Kontsept «khan»(한) u suchasniy koreys'kiy maliy prozi. V: Teksti dopovidey mizhnarodnoyi naukovoyi konferentsiyi "Koreyeznavstvo v Ukrayini: suchasnist' i perspektivi». Kiyiv. 228-234].

Семенюк, І. В. (2011), Цінності та об’єкти поклоніння в соціокультурних системах Сходу. Грані. № 6. 54-59 [Semenyuk, I. V. (2011), Tsinnosti ta obyekti pokloninnya v sotsiokul'turnikh sistemakh Skhodu. Hrani. No 6. 54-59].

Семенюк, I. В. (2013), Особливості історичної традиції південнокорейського суспільства, Гуманітарний вісник ЗДІА. № 54. 106-115 [Semenyuk, I. V. (2013), Osoblivosti istorichnoyi traditsiyi pivdennokoreys'koho suspil'stva, Humanitarniy visnik ZDIA. No 54. 106-115]. 